\title{
Article
}

\section{IN MEMORIAM: PROFESSOR PHILIP L. PEARCE (1951-2020)}

Alejziak, Wiesław, Ujma, Dorota and Sharpley, Richard Anthony john

Available at http://clok.uclan.ac.uk/38463/

Alejziak, Wiesław, Ujma, Dorota ORCID: 0000-0001-5092-6782 and Sharpley, Richard Anthony john ORCID: 0000-0002-2135-3206 (2021) IN MEMORIAM: PROFESSOR PHILIP L. PEARCE (1951-2020). Folia Turistica, 56 . ISSN 08673888

It is advisable to refer to the publisher's version if you intend to cite from the work. http://dx.doi.org/10.5604/01.3001.0014.8966

For more information about UCLan's research in this area go to http://www.uclan.ac.uk/researchgroups/ and search for <name of research Group>.

For information about Research generally at UCLan please go to http://www.uclan.ac.uk/research/

All outputs in CLoK are protected by Intellectual Property Rights law, including Copyright law. Copyright, IPR and Moral Rights for the works on this site are retained by the individual authors and/or other copyright owners. Terms and conditions for use of this material are defined in the policies page.

\section{CLoK}

Central Lancashire online Knowledge www.clok.uclan.ac.uk

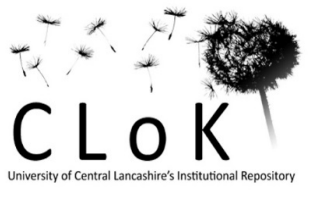




\section{IN MEMORIAM: PROFESSOR PHILIP L. PEARCE (1951-2020)}

\section{Wiestaw Alejziak*, Dorota Ujma**, Richard Sharpley***}

On August 11, 2020, the community of tourism researchers and academics suffered a great loss. Professor Philip L. Pearce passed away on that day. He was not only a world-renowned researcher of tourist behaviour, but also an extremely popular and respected colleague. His popularity was mainly due to his unique character traits and openness to scientific cooperation, which we personally experienced ourselves. Professor Pearce greatly contributed to the development of research and knowledge about tourism, especially in the field of psychology, but much of his work reached beyond this field too (as exemplified by

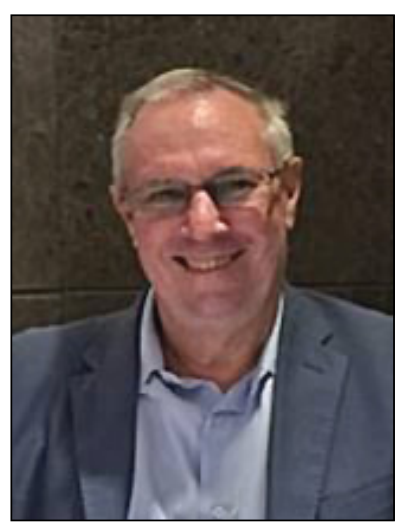
projects containing accurate observations and diagnoses on the methodology of tourism research). As the Editorial Board of the journal "Folia Turistica", we were lucky and extremely proud to work with the Professor for five years, at the time when he was a member of our Scientific Council. Bearing in mind the Professor's great influence on the development of research and knowledge in tourism, as well as the high esteem and recognition he enjoyed both among us and our readers, we will try to present here his scientific achievements and the personal characteristics of this great scholar.

Professor Philip L. Pearce was born in 1951 in Adelaide, Australia, where his ancestors had arrived a hundred years earlier, as some of the first

* (D) https://orcid.org/0000-0002-0604-7577; Assoc. Prof., Ph. D, University of Physical Education in Kraków, Faculty of Tourism and Recreation, Institute of Entrepreneurship and Management; e-mail: wieslaw.alejziak@awf.krakow.pl

** (D) https://www.uclan.ac.uk/academics/dr-dorota-dot-ujma, https://orcid.org/0000-0001 -5092-6782; The University of Central Lancashire, Course Leader, e-mail: dujma@uclan.ac.uk,

*** (iD https://www.uclan.ac.uk/academics/professor-richard-sharpley; https://orcid.org/ 0000-0002-2135-3206, The University of Central Lancashire, Professor of Tourism and Development, e-mail: RAJSharpley@uclan.ac.uk 
English and Scottish settlers in the South Australia. From his early school years, he was active and willing to compete, also in the field of sport (especially cricket). From his youth, he followed his family members' important and interesting hobby, and was involved in breeding and showing Australian Shepherd Dogs, giving him exposure to tourism. Initially, his interest in education was in literature, and young Pearce thought to become an English teacher. However, his interest in psychology also appeared fairly early, which was reflected in his undertakings and graduating with honours from the University of Adelaide in 1972. In 1973, he started working as an Associate Lecturer of Psychology at the University of South Australia, and after completing postgraduate studies in 1974, he received a research scholarship to Oxford for a doctorate in social psychology. The period in Oxford (19741977) turned out to be extremely significant for his further scientific career, partially due to contacts and friendships with experienced scientists, who influenced his interests and the way he conducted his research. For example, the important ones were Peter Collet - the author of an excellent book in the field of social communication, entitled The Book of Tells and Michael Argyle, the author of pioneering works on social skills, relationships and happiness. An important event for the Professor's future career was the invitation from Professor Jafar Jafari (the founder and editor-in-chief of "Annals of Tourism Research", established only a few years earlier, but by then, already a very prestigious journal), to the editorial cooperation with the mission of broadening the profile of the journal by adding the psychological themes and topics. The focus of Annals at that time was on sociology and anthropology. Pearce tried to promote the best work in the field of tourism psychology, collaborating closely with such eminent scholars of social research in tourism as Dean MacCannell and Erik Cohen. They, at the time, pursued research on tourism authenticity, which was close to Pearce's own interests. The crowning achievement of the Oxford period in the Professor's life and career was completing his doctoral dissertation in the field of Experimental Psychology on The Social and Environmental Perceptions of Overseas Tourists. In this work, supervised by Professors Peter Collett and Michael Argyle, and focusing on the social and environmental context of the phenomenon of tourism, he mainly investigated the social and environmental perceptions of overseas tourists in Europe.

Exactly after 3 years, 2 months and 14 days - as he admitted in an interview - he returned to Australia with his Ph.D. He started to work as an Associate Lecturer of Psychology at Flinders University, in the Social Psychology Department that was being established there. Two years later, he moved to James Cook University, where he worked as a Senior Lecturer of Psychology between 1983-1987. Then, from 1988 to 1989, he worked as Research Director at the National Centre for Studies in Travel \& Tourism. In 1990, he became the first Foundation Professor of Tourism in Australia 
and returned to work at James Cook University, with which he was associated until the end of his professional career. He rightly considered it a great privilege to be awarded the title of Australia's First Tourism Professor and appreciated it very much. Undoubtedly, this had great impact on his approach to work and his views on the roles that mentors should play in the learning process. We had the opportunity to observe this personally, working with the Professor on the occasion of publishing a special issue of the journal "Folia Turistica" Master Classes (edited by Alejziak 2011), devoted to the role of eminent academics in the contemporary shaping of knowledge, to which we invited Professor Pearce along with other outstanding researchers and tourism theorists from around the world. Two of the authors of this article had the opportunity and pleasure to get to know the Professor better (although only via e-mail) while editing the entire issue (W. Alejziak), translating his text to Polish and preparing his academic biography (D. Ujma). Below, we present a few of the Professor's research directions, included in that special issue (Ujma 2011, p. 206):

\begin{abstract}
He publishes widely in psychology and tourism studies journals, and his general research interests endeavour to gain a better understanding of tourist behaviour and experience. This specialist tourist behaviour research area provides a sound core to help understand tourism in general. His interests have developed in several ways. He focuses in part on why people participate in tourism and therefore conducts studies of tourist motivation. He has also developed an understanding of what tourists do on site (e.g. at theme parks, at museums, at attractions and in everyday tourist settings). Such studies consider tourists' emotional reactions, attitudes, behaviours and cross-cultural travel experiences. Additionally, his interest in tourist behaviour extends to the consequences of tourists' actions. Here, there is a concern with tourists' satisfaction and learning as well as with the sustainability of what they do, including their impact on local people and places. These interests may be seen in part as encouraging everyone to celebrate, study and enjoy the fun of well managed tourism as a part of human flourishing and wellbeing.
\end{abstract}

Perhaps the greatest of Professor P. Pearce's contributions to our understanding of tourism is his research on conceptualising tourist behaviour. In this field, he was able to brilliantly use various concepts, methods and research techniques developed in the field of social psychology, and skilfully transpose them to the field of tourism. His research devoted to tourist motivations, tourist satisfaction, authenticity or factors determining the choice of a destination and its perception are among the most frequently cited. One of his first monographs, The Social Psychology of Tourist Behaviour (Pearce 1982b), published by Pergamon Press Oxford in 1982, is considered a breakthrough in the field of psychology of tourist behaviour. In the same year, the Professor published a respected article in the Annals of Tourism Research, in which he presented an innovative approach to researching the perception 
of tourist attractions, as well as factors determining their image (Pearce 1982a). In general, the already mentioned 1980 s were a very intense and "fruitful" period in the Professor's career, enabled largely by two research scholarships: first, the G. Murray scholarship, which allowed him to study and conduct research in Oxford, and then, the Fulbright scholarship, which in 1981-1982 made it possible for him to work at Harvard University.

An important direction of Professor Pearce's research and his later publications was the role of tourism for broadly understood social relations, and his book - co-authored with G. Moscardo and G. Ross - Tourism community relationships, became the leading academic textbook in this area. An intriguing thread in Professor Pearce's research was the issue of free time and the importance of psychology within leisure studies. As a part of this thread, he published several original pieces on positive psychology, concerning well-being, happiness and good life (Pearce, Filep, Ross, 2011), as well as the relations between tourism and the broadly understood topic of humour (Pearce, Pabel 2014). In the 1990s, as one of the first investigators, Pearce initiated his research on the phenomenon of backpacking and continued with it, both independently and on various research teams. It remains a noticeable part of his academic endeavours.

In the Professor's entire opus, there are many relevant works for the development of tourism research, and it is difficult to identify the most important ones. Among them, there would probably be those published in 1988. The first is an article written by an excellent team of authors, on the methodology of tourism research, which showed various methodological nuances of such research and its rarely noticed complexity (Dann, Nash, Pearce, 1988a). The second is the book The Ulysses factor: Evaluating visitors in tourist settings (Pearce 1988b), published by Springer. Pearce advocates the development of research on tourist behaviour and emphasizes the central importance of experiences in the study of tourism, whilst noticing that the majority of such studies are conducted by Australian, British and American researchers.

Tourist behaviour: Themes and conceptual schemes, published in 2005 by Channel View, is one of Professor Pearce's most cited and appreciated works. In it, he presented expansion of the Travel Career Ladder (TCL) model, on which he had worked with his former Ph.D. student, Lui Lee. This theoretical model was developed and modified to the Travel Career Pattern, and work on it partially led to the Tourist behaviour and the contemporary world (Pearce 2011b), written in similar vein. Professor Pearce was often invited as a keynote speaker and a very active participant in various conferences, at which he willingly presented the results of his research and was a contributor in many discussions.

Professor Pearce often expressed his views on tourism education, especially at the academic/HE level. This thread appears in the article titled 
Respecting the Past, Preparing for the Future: The Rise of Australian Academic Tourism Research. It was included in the project of the "Master Classes" a special two-volume bilingual edition of the journal "Folia Turistica", published on the $35^{\text {th }}$ anniversary of its publisher, Faculty of Tourism and Recreation at Akademia Wychowania Fizycznego (University of Physical Education) in Kraków. We had the opportunity to carefully study this piece: D. Ujma, during its translation to Polish, and W. Alejziak in the process of editing it for the needs of the journal. In this article, the Professor brilliantly outlined the conditions and circumstances regarding the rapid progression of tourism academic education in Australia, which in just a decade (starting from 1987), developed almost spectacularly. In his words (Pearce 2011a, p. 190):

The upgrading of the colleges of advanced education and the institutes to university status provided them not only with a new prestige but a mandate for change and a hunt for more students. Thus the old names with the common designation CAE (College of Advanced Education) - such as Hawkesbury College, Gatton College, Northern Rivers CAE, Footscray Institute, Kuring-gai $C A E$ and Gold Coast CAE - became some of the new ones in early tourism and have since morphed or merged into substantial concerns - respectively as the University of Western Sydney, University of Queensland Gatton and Ipswich, Southern Cross University, Victoria University, University of Technology Sydney and Griffith University Gold Coast.

In addition to presenting the Australian education system, the quoted article contains accurate directions towards factors influencing the effectiveness of tourism research. They stemmed from nearly 30 years concerning the Professor's observations of Australian tourism research, including comments on the political environment. In the paper, their genesis, conditions and prospects for further development were presented, with an indication of these factors and procedures that should be utilised by contemporary researchers from around the world to intensify tourism research. Some of the themes in the article posed quite a challenge to interpret and translate. Therefore, it was necessary to contact Philip Pearce via e-mail to discuss and digest his meaning, allowing for it to be adequately expressed in Polish. Professor Pearce responded quickly and was generous with his time and patience. He seemed genuinely enthusiastic about discussing any themes that hopefully resulted in a more accurate translation.

For his research and teaching, Professor Pearce was awarded many honorary titles. For example, in 2008, the Australian Learning and Teaching Council, recognising the Professor's strive towards excellence in both tourism research and teaching, distinguished him for his outstanding contribution to the development of tourism education. The International Studies University in China bestowed on him the title of honorary professor. Tourism studies in 
China and in Asia occupied an important place in the Professor's research output. In the $21^{\text {st }}$ century, it was one of the dominant directions of his publications. Cooperation with researchers from China, the Country of the Middle (中国, or Zhōng guó, which in Mandarin - the main language of China - means the Central State: a country surrounded by borders) is, in fact, an important element in Pearce's research career. This is evidenced by the relatively high number of joint publications with researchers from this country (see attached lists of publications).

Professor Pearce was a sought after editor and member of scientific councils for many prestigious journals, including: Annals of Tourism Research (since 1982); Asia Pacific Journal of Tourism Studies (since 1996); Progress in Tourism and Hospitality Research (1994-1998); Journal of Teaching in Travel and Tourism (since 2008); European Journal of Tourism (since 2008). He was also the Foundation Editor of the Journal of Tourism Studies (1990-2005). In 2015, he became a member of the Scientific Council of our journal - Folia Turistica, and remained in this position until his untimely death ${ }^{1}$. Professor Pearce was one of the most world-renowned tourism academics, who not only shaped the foundations of tourism studies, but also promoted it and set new directions in tourism research. The prestigious International Academy for the Study of Tourism (IAST), of which Professor Pearce was a founding member, comprised an international organisation supporting all these activities.

Professor Pearce supervised many doctoral dissertations and some of his doctoral students have joined the group of outstanding international tourism researchers. Sebastian Filep and Pierre Benckendorff are such examples, and we singled them out because they wrote an excellent article on Professor Pearce's contribution to the development of tourism research, published as a part of a special series of works on pioneers and world eminent scholars in the field of tourism (Filep and Benckendorff 2016). Such a series has been published for some time in the journal Anatolia. An International Journal of Tourism and Hospitality Research and on the website of the aforementioned IAST, (http://www.tourismscholars.org/anatolia portrait.php). In their engaging and emotional presentation of Professor Pearce's career - for he was not only a great role-model for them but, as they admit, also a friend - they quote others confirming the Professor's spe-

${ }^{1}$ Unfortunately, it was not meant for Philip Pearce to visit Poland and Kraków, which he announced several times in the e-mails that I (W. Alejziak) had the pleasure to exchange with him on various occasions. An example may be an exchange summarising our cooperation on the project "Master Classes", already mentioned in this article, where Professor Pearce wrote in one of the e-mails “... Wieslaw, Your courtesy and helpfulness is appreciated. Please consider that visiting Poland is on my future agenda and I will start with visiting you. Exactly when I do not know but I hope it will not be too far in the future ". Later in another e-mail, with his sense of humour he added -" ... I hope that by publishing with you I may one day get to visit Krakow!"). 
cial connection with his doctoral students. One of them was the Professor's long-term personal assistant, Anne Sharp, who argued that: “... Pearce could turn a crying, aimless, desperate $\mathrm{Ph} . \mathrm{D}$. student into one who was laughing and highly motivated in 10 min." (Filep, Benckendorff 2016, p. 294). S. Filep and P. Benckendorff also cite another colleague, Karen Hughes, who spoke about him in this way (Filep, Benckendorff 2016, p. 295):

A youthful enthusiasm for life ... He relishes the thrill of solving a puzzle, problem or conundrum. He is generous with his time and expertise-always willing to discuss ideas, give advice and share resources. Philip has always been very supportive of his research students. He has been instrumental in creating a talented and cohesive network of ex-students who share his ideals and strive to emulate his innovative, thorough and insightful approaches to tourism research. He also has a great sense of humour.

Several tourism researchers from around the world have shared similar views about Professor Pearce. The number of e-mails that reached us, as members of the TRINET network shortly after his death, was astounding. The touching farewells and memories played tribute to how great a man Professor Philip L. Pearce was. For instance, Professor Chris Ryan, the long-term editor-in-chief of Tourism Management, one of the journals considered to be most prestigious in the field of tourism, published the following tribute (http://www.tourismscholars.org/memoriam_pearce.php):

It (Professor Pearce's death - added by authors) leaves us bereft of his friendship and sense of sharing - whether it was a guest lecture on humour in tourism, showing games to our students, or sharing stories of travel and companionship. As I write these words - I realise how much I have left out. The First Tourism Professor in Australia, a Fullbright Scholar at Harvard University, a visiting professor at so many universities. For me, as for many of us, he was quite simply, our friend.

The Channel View Publishers, who issued several of the Professor's fundamental books, shared their touching farewell shortly after his death (https://channelviewpublications.wordpress.com/2020/08/11/philip-pearce/):

We were shocked and saddened to hear about the sudden death of author and friend of Channel View, Philip Pearce, this week. In this post Sarah shares her memories of him. I had the pleasure of knowing Philip for many years and working with him on a number of occasions. He was a lovely, kind man and a brilliant mind. He always showed such care for those around him and all of us at Channel View appreciated his great support of the company and the enthusiasm with which he tackled his work. It was always good to see Philip at conferences - if he was presenting it was bound to be a not-to-be-missed paper [...]. Channel View are proud to have published Philip's work and we're grateful and glad to have known him and worked with him for so long. We will raise a glass 
to him when we can all be together again and I will certainly specially remember him at Big Bash time and cheer on the Brisbane Heat. We are thinking of his wife, Hera, and all his family. He will be greatly missed.

\section{Sarah, Ellie, Tommi, Anna, Laura, Flo, Alice and Rose}

Professor Pearce's academic achievements are extremely rich, exceeding (in quantitative terms) several hundred publications. They are cited not only when tourism is researched from a psychological perspective, which Professor Pearce represented, but also many others (according to Google Scholar - number of citations: 22,186; H-index: 69; Index I-10: 210, as of 02 Jan. 2021). The attached list of the Professor's publications is presented in a slightly unusual format: the first part follows the list prepared by him in 2011 with regard to the aforementioned project "Master Classes" for the special edition of the journal "Folia Turistica" (2011, 25 (1)). The second part consists of a list generated by Google Scholar, for the period from 2011 until his death; in fact, until the end of 2020. Some articles and chapters are still forthcoming, to be published shortly. For example, Professor Richard Sharpley, in a private correspondence from 11 Jan. 2021, states the following:

Two of Philip Pearce's most recent works are chapters that he contributed to the Routledge Handbook of the Tourist Experience (in press, Sharpley (Ed.)). In one, he revisits the concept with which he is arguably most commonly associated, namely, the travel career model, critically assessing its historical development and contemporary applications as well exploring its future contribution to understanding tourist motivation. In the other, co-authored with Zohre Mohammadi and possibly his final work, he proposes a new concept - the orchestra model - as a framework for analysing the tourist experience. Together, these chapters are evidence of his continuing enthusiasm for, and contributing to, extending knowledge and understanding of the social phenomenon that is tourism.

Even though we certainly have not managed to include all of the Professor's works (especially those published over the last nine years), the list remains incredibly impressive. The value of these publications, his academic legacy, lies not only in their quantity, but mainly in their quality, which is most likely to be confirmed by all of us who have had the opportunity to read Professor Pearce's works.

We have lost many of the "leading lights" of tourism in the last few years and we miss them. Although they have left us, their work remains. It is up to us (the Academy) to build on their ideas and contributions. 


\section{References}

Alejziak W. (ed.) (2011), “The Master Classes. Folia Turistica” - Special Edition Published on the 35 Anniversary of the Tourism and Recreation Faculty at the University School of Physical Education in Kraków, Vol. 25(1), pp. 451.

Benckendorff, P. J., Pearce, P. L. (2003). Australian tourist attractions: The links between organizational characteristics and planning. "Journal of Travel Research", Vol. 42, pp. 24-35.

Dann, G., Nash, D., Pearce, P. (1988). Methodology in tourism research. "Annals of Tourism Research", Vol. 15, pp. 1-28.

Filep S., Benckendorff P. (2016), Philip L. Pearce: foundation professor of tourism, "Anatolia. An International Journal of Tourism and Hospitality Research", Vol. 27 (2), pp. 290-297.

Filep, S., Pearce, P. L. (Eds.). (2013). Tourist experience and fulfilment: Insights from positive psychology, New York, Routledge.

Pearce, P. L. (1982a). Perceived changes in holiday destinations, "Annals of Tourism Research", Vol. 9, pp. 145-164.

Pearce P. L. (2011a). Respecting the Past, Preparing for the Future: The Rise of Australian Academic Tourism Research. "Folia Turistica", Vol. 25 (1), pp. 187-205.

Pearce P. L. (1982b). The social psychology of tourist behaviour, Oxford, Pergamon Press.

Pearce P. L. (2005). Tourist behaviour: Themes and conceptual schemes, Clevedon, Channel View.

Pearce, P. L. (2011b). Tourist behaviour and the contemporary world, Bristol, Channel View.

Pearce, P. L. (1988). The Ulysses factor: Evaluating visitors in tourist settings, New York, Springer-Verlag.

Pearce, P. L., Filep, S., Ross, G. (2011). Tourists, tourism and the good life, New York, Routledge.

Pearce P. L., Moscardo, G., \& Ross, G. F. (1996). Tourism community relationships, Oxford, Pergamon.

Pearce P. L., Pabel, A. (2014). Tourism and humour, Bristol, Channel View.

Pearce P. L., Lee, U-I. (2005), Developing the travel career approach to tourist motivation, "Journal of Travel Research", Vol. 43, pp. 226-237.

Sharpley R. (forthcoming) (Ed.) The Routledge Handbook of the Tourist Experience, Routledge.

Ujma D. (2011), A Brief Outline of the Academic Achievements of Philip. L. Pearce and His Contribution to the Development of Tourism Research, " Folia Turistica", Vol. 25(1), pp. 206-207. 
List of Professor Ph. L. Pearce's publications up to 2011 (this list was prepared by Philip Pearce for the special edition of "Folia Turistica - Master Classes")

\section{MONOGRAPHS:}

Pearce, P.L. (Ed.) (in preparation) The Study of Tourism. Foundations from Psychology. Elsevier.

Murphy, L. Moscardo, G., Benckendorff, P. \& Pearce, P.L. (2011), Tourist Shopping Villages. New York: Routledge.

Pearce, P.L., Filep, S. \& Ross, G. (2011), Tourists, Tourism and the Good Life. New York: Routledge.

Pearce, P.L., Murphy, L. \& Brymer, E. (2009), Evolution of the backpacker market and the potential for Australian Tourism. Brisbane: CRC Sustainable Tourism.

Pearce, P.L. (2005), Tourist behaviour: Themes and conceptual schemes. Clevedon: Channel View.

Pearce, P.L., Morrison, A.M., \& Rutledge, J.L. (1998), Tourism: Bridges across continents. Sydney: McGraw-Hill.

Pearce, P.L., Moscardo, G.M., \& Ross, G.F. (1996), Tourism community relationships. Oxford: Pergamon Press.

Pearce, P.L. (1990), The backpacker phenomenon: Preliminary answers to basic questions. Townsville: James Cook University of North Queensland.

Pearce, P.L. (1988), The Ulysses Factor: Evaluating visitors in tourist settings. New York: Springer-Verlag.

Smithson, M., Amato, P., \& Pearce, P.L. (1983), Dimensions of helping behaviour. Oxford: Pergamon Press.

Pearce, P.L. (1982), The social psychology of tourist behaviour. Oxford: Pergamon.

\section{SELECTED ACADEMIC PUBLICATIONS:}

Pearce, P.L. (2010), New directions for considering tourists' attitudes towards others. Tourism Recreation Research, Vol. 35 (3), pp. 251-258.

Tang, L., Morrison, A.M., Lehto, X.Y., Kline, S. \& Pearce, P.L. (2009) Effectiveness criteria for Icons as Tourist Attractions: A comparative study between the U.S. and China. Journal of Travel and Tourism Marketing, Vol. 26 (3), pp. 284-302.

Moscardo, G., \& Pearce, P.L. (2009), Connecting Traveller Behaviour to Information Source Use. Sea Change: tourism \& hospitality in a dynamic world. Proceedings of the 18th Tourism and Hospitality Education and 
Research CAUTHE Conference. 10-13 February 2009, Western Australia, Australia.

Qian, J., \& Pearce, P.L. (2009), A model of tourism crowding management at cultural sites in China. Role of Hospitality and Tourism in Globalization. Proceedings of the $8^{\text {th }}$ Asia Pacific Forum for Graduate Students' Research in Tourism, Seoul, Korea. 8-10 July, 2009.

Coghlan, A., \& Pearce, P.L. (2009), Tracking affective components of satisfaction. Journal of Tourism and Hospitality Research advance on line publication, pp. 1-17.

Pearce, P.L. (2009), Now that is funny Humour in Tourism Settings. Annals of Tourism Research, Vol. 36 (4), pp. 627-644.

McCarthy, B., Moscardo, G., Murphy, L., \& Pearce, P.L. (2009), Music-tourism networks A study of three festivals in Queensland. In: Metin Kozak, Juergen Cnoth and Luisa L.A. Andrew (Eds.) Advances in Tourism Destination Marketing: Managing networks (pp 74-87). Routledge: London and New York.

Moscardo, G., McCarthy, B., Murphy, L. \& Pearce, P. (2009), The importance of networks in special interest tourism: Case studies of music tourism in Australia. International Journal of Tourism Policy, Vol.2(1/2), pp. 5-23.

Pearce, P.L. (2009), Tourism Research and the Tropics: Further Horizons. Tourism Recreation Research, Vol. 34(2), pp. 107-121.

Pearce, P.L. (2009), The Relationship between positive psychology and Tourist Behavior Studies. Tourism Analysis, Vol. 14, pp. 37-48.

Pearce, P.L., \& Kang, M. (2009), The effects of prior and recent experience on continuing interest in tourist settings. Annals of Tourism Research, Vol. 36 (2), pp. 172-190.

Murphy, L., Pearce, P.L., Benckendorff, P. \& Moscardo, G. (2008), Tourist Shopping Villages; Challenges and Issues in Developing regional Tourism. In: S. Richardson, L. Fredline, A. Patiar and M. Ternel (Eds.) Tourism and Hospitality research, training and Practice: Where the bloody hell are we? Proceedings of the $18^{\text {th }}$ Annual Council of Australian University Tourism and Hospitality CAUTHE conference 11-14 Feb, 2008.

Pearce, P.L. (2008), Studying tourism entertainment through micro-cases Tourism Recreation Research, Vol. 33 (2), pp.151-163.

Pearce, P.L. (2008), Tourism and Entertainment: Boundaries and Connections Tourism Recreation Research, Vol. 33 (2), pp. 125-130.

Cottrell, S., Pearce, P.L. \& Arntzen, J. (2008), Tourism as an Income Earner Botswana, Notes and Records, Vol. 39, pp, 13-22.

Pearce, P.L. (2008), Understanding how tourism can bring socio-cultural benefits to destination communities In: G. Moscardo (Ed.) Building Community Capacity for Tourism Development. CABI. P29-40. 
Pearce, P.L. and Maoz, D. (2008), Novel insights into the identity changes among backpackers. Tourism Culture and Communication, Vol. 8, pp. 27-43.

Pearce, P.L., Son, A., and Wu, Y. (2008), Developing a framework for assessing visitors' responses to Chinese cities. China Tourism Research, Vol. 4(1) pp. 22-44.

Pearce, P.L. (2008), The nature of rainforest tourism: Insights from a tourism social science research programme. In: N. Stork \& S. Turton (Eds.), The wet tropics rainforests of Australia. Oxford:Blackwells

Pearce, P. L., \& Coghlan, A. (2008), The dynamics behind volunteer tourism in S Wearing and K. Lyons (Eds.) Journeys of Discovery: international case studies in Volunteer Tourism. CABI, pp. 130-143.

Pearce, P.L. (2008), In Search of the Chinese People; Cross-cultural Vignettes. Experiencing China: Travel Stories by Tourism Experts. pp. 215 - 235.

Murphy, L., Moscardo, G., Benckendorff, P., \& Pearce, P. L. (2008), Tourist Shopping Villages-Exploring Success and Failure. In: D. Martin and A. Woodside Tourism Management p 405-423. Wallingford, Oxon: CABI.

Chen, T. and Pearce, P.L. (2008), A comprehensive approach to Asian seasonality patterns in Tourism Proceedings of the APTA conference Bangkok, Thailand 9-12 th July 2008. pp. 465-474.

Pearce, P.L. and Kang, M. (2008), Exploring traveler loyalty to types of tourist settings Proceedings of the APTA conference Bangkok, Thailand 9-12 $2^{\text {th }}$ July 2008, pp. 120-128.

Pearce, P.L., \& Moscardo,G. (2007), An Action Research Appraisal of Visitor Centre Interpretation and Change. Journal of Interpretation Research, Vol. 12 (2) pp. 29-50.

Pearce, P.L. (2007), Local applications of global tourism trends Cross Cultural Collaboration in Hospitality and related services. Synergies and Future Possibilities. Symposium Cairns October 2007, pp. 1-16.

Pearce, P.L. (2007), Sustainability Research and Backpacker Studies: Intersections and Mutual Insights. In: K. Hannam \& I. Ateljevic (Eds.) Backpacker Tourism Concepts and Profiles. pp. 38-53. Clevedon: Channel View.

Pearce, P.L.(2007), Asian Tourism educators: Views of their employment and possibilities for interaction with industry. Journal of Teaching in Travel and Tourism, Vol. 7(1), pp. 63-76.

Pearce, P.L., \& Foster, F. (2007), A "University of Travel": Backpacker learning. Tourism Management, Vol. 28 (5), pp. 1285-1298.

Pearce, P.L. (2007) Persisting with authenticity. Tourism Recreation Research, Vol. 32(2), pp. 86-90

Moscardo, G., \& Pearce, P.L. (2007), The Rhetoric and Reality of Structured Tourism Work Experiences: A Social Representational Analysis. Tourism Recreation Research, Vol. 32(2), pp. 21-28. 
Yagi, C., \& Pearce, P.L. (2007), The influence of appearance and the number of people viewed on tourists' preferences for seeing other tourists. Journal of Sustainable Tourism, Vol.15(1), pp. 28-43.

Pearce, P.L. (2007), Respecting the past, preparing for the future; twenty five years of Australian tourism research. In: I. McDonald (Ed.) Tourism Past Achievements, Future Challenges, pp. 1-16. CAUTHE conference proceedings Sydney: UTS.

Pearce, P.L. (2006), The value of a benchmarking approach for assessing service quality satisfaction in environmental tourism. In: B. Prideaux, G. Moscardo and E. Laws (Eds.), Managing Tourism and Hospitality Services, pp. 282-299. London:CABI.

Moscardo, G.,\& Pearce,P.L. (2006), Internet use, site visits and destination images: Implications for Sustainable Tourism on the Great barrier reef. In G.R. Jennings \& S. W. Beeton (Eds.) New Frontiers in Global Tourism- Trends and competitive challenges, $37^{\text {th }}$ Annual conference Proceedings Travel and Tourism Research Association. Dublin, Ireland: TTRA.

Pearce, P.L., \& Benckendorff, P. (2006), Benchmarking, usable knowledge and tourist attractions. Journal of Quality Assurance in Hospitality and Tourism, Vol. 7(1/2), pp. 29-52.

Pearce, P.L. (2006,) Backpacking and backpackers-A fresh look. Tourism Recreation Research, Vol. 13(3), pp. 5-10.

Pearce, P.L. (2005), Professing tourism: Tourism academics as educators, researchers and change leaders. Journal of Tourism Studies, Vol. 16(2), pp. 21-33.

Pearce, P.L. (2005). Australian tourism education: The quest for status. Journal of Teaching in Travel \& Tourism, Vol. 5(3), pp. 251-267.

Pearce, P.L., \& Vogt, H. (2005), Warriors, emperors and tourists: Environmental setting factors and visitor comfort at two Chinese tourist attractions. China Tourism Research, Vol.1(2-3), pp. 161-177.

Pearce, P.L. and Lee, U-I. (2005), Developing the travel career approach to tourist motivation. Journal of Travel Research, Vol. 43, pp. 226-237.

Son, A., \& Pearce, P.L. (2005), Multi-faceted image assessment: International students' views of Australia as a tourist destination. Journal of Vacation Marketing, Vol. 18(4), pp. 21-35.

Pearce, P.L., \& Moscardo, G. (2005), Domestic and visiting friends and relatives tourism. In: D. Buhalis \& C. Costa (Eds.), Tourism business frontiers: Consumers, products and industry (pp. 48-55). Oxford: Elsevier.

Pearce, P.L. (2005), Great divides or subtle contours? Contrasting British, North American/Canadian and European backpackers. In: B. West (Ed.), Down the road: Exploring backpacker and independent travel (pp. 131-151). Perth: API Network. 
Pearce, P.L. (2005), The role of relationships in the tourist experience. In: W. Theobald (ed.), Global Tourism (3rd edn) (pp. 103-122). Oxford: Butterworth Heinemann.

Pearce, P.L. (2005), Tourist watching: Arguments for and recent applications of systematic observation. In: Seung-Jin Suh \& Yeong-Hyeon Hwang (Eds.), 'New tourism for Asia-Pacific', The 11th APTA Conference Proceedings, Koyang, Korea, 7-10 July 2005 (pp. 566-575). Pusan, Korea: Dong-A University.

Pearce, P. (2005), Understanding environmental optimists and pessimists and Australia's Great Barrier Reef. In: N.K. Saxena (Ed.), Recent advances in marine science and technology, 2004 (pp. 263-271). Honolulu, Hawaii: PACON International.

Pearce, P.L. \& Moscardo, G. (2004), Assessing Market Convergence and Divergence: Studies of visitors to Australia's Great Barrier Reef. In: R. MacLellan, T. Baum, A. Goldsmith, J. Kokkranikal, E. Losekoot, S. Miller, A. Morrison, D. Nickson, J.S. Taylor \& K Thompson (Eds.), Tourism State of the Art II Conference, University of Strathclyde, Glasgow, 27 June - 30 June 2004 (18 pp.). Glasgow: The Scottish Hotel School, University of Strathclyde.

Pearce, P.L., \& Moscardo, G. (2004), Coming back for more: Experiences and repeat behaviour on Australia's Great Barrier Reef. Proceedings of 2004 Annual TTRA Conference "Measuring the tourism experience: When experience rules, what is the metric of success?" Montreal, Quebec, Canada, June 20-23, 2004.

Pearce, P. \& Son, A. (2004), Youth tourism markets in Australia: Comparing travel behaviours of international students and backpackers. Tourism, Vol.52(4), pp. 341-350.

Pearce, P.L. (2004). History, practices and prospects for the $\mathrm{PhD}$ in Tourism. Journal of Teaching in Travel \& Tourism, Vol. 4(3), pp. 31-49.

Pearce, P.L. (2004), The functions and planning of visitor centres in regional tourism. Journal of Tourism Studies, Vol. 15(1), 8-17.

Moscardo, G., \& Pearce, P.L. (2004), Life cycle, tourist motivation and transport: Some consequences for the tourist experience. In: L. Lumsdon \& S.J. Page (Eds), Tourism and transport: Issues and agenda for the new millennium (pp. 29-43). Oxford: Elsevier.

Pearce, P.L. (2004), Theoretical innovation in Asia Pacific tourism research. Asia Pacific Journal of Tourism Research, Vol. 9(1), pp. 57-70.

Ormsby, J., Moscardo, G., Pearce, P., \& Foxlee, J. (2004), A review of research into tourist and recreational uses of protected natural areas. Research Publication No. 79. Townsville: Great Barrier Reef Marine Park Authority.

Rocharungsat, P., \& Pearce, P.L. (2004), Community-based tourism: The perspectives of professionals. Proceedings of Third Asia Pacific Forum 
for Graduate Students Research in Tourism, "New frontiers in tourism research: New perspectives and new approaches", Beijing, China, Sept. 22-24 (pp. 978-998). Beijing: Beijing International Studies University.

Pearce, P.L., \& Yagi, C. (2004), Methodological innovation in Asia Pacific tourism research. In: K. Chon, C. Hsu \& N. Okamoto (Eds.), "Globalization and tourism research: East meets West", Conference Proceedings Asia Pacific Tourism Association Tenth Annual Conference, Nagasaki, Japan, 4-7 July 2004 (pp. 619-631).

Lee, U-I (Lui), \& Pearce, P.L. (2003), Travel career patterns: Further conceptual adjustment of Travel Career Ladder. In: Jae-Kyoon Jun (Ed.), Second Asia Pacific forum for Graduate Students Research in Tourism, 2-4 October, 2003, Busan, Korea (pp. 65-78). Korea: The Korea Academic Society of Tourism \& Leisure.

Son, A., \& Pearce, P.L. (2003), Overseas students' image of Australian cities: Applying a sketch map methodology. In: Jae-Kyoon Jun (Ed.), Second Asia Pacific forum for Graduate Students Research in Tourism, 2-4 October, 2003, Busan, Korea (pp. 154-169). Korea: The Korea Academic Society of Tourism \& Leisure.

Pearce, P., \& Burke, A. (2003), The role of visitor centres in emerging Asia Pacific tourism destinations: Concepts and research contributions for best practice. In T. Griffin \& R. Harris, "Current research, future strategies: Bridging uncertainty", Proceedings of the Asia Pacific Tourism Association (APTA) 9th Annual Conference, July 6-9 2003, Sydney (pp. 525-536). Sydney: School of Leisure Sport \& Tourism, University of Technology Sydney.

Pearce, P.L. (2003), To the $\mathrm{PhD}$ and beyond: Challenges and prospects for advanced tourism and hospitality education. In: K. Chon \& I. Yang (Eds.), Conference Proceedings I of First APAC-CHRIE Conference "Hospitality, Foodservice and Tourism Research and Education: 'The Asian Waves'", Seoul, Korea, May 21-23, 2003, pp. 710-718.

Pearce, P.L., \& Hyvonen, T. (2003), Litter in the city: Visitor perceptions and sustainable practices for urban tourism. Tourism, Vol. 51(2), pp. 193-204.

Pearce, P.L. (2003), Chapter 9: Motivation for pleasure travel. In R. McIntosh, C. Goeldner, \& J.R. Brent Ritchie (Eds.), Tourism: Principles, practices, philosophies (9th ed.) (pp. 241-259). Hoboken, New Jersey: John Wiley \& Sons.

Benckendorff, P.J., \& Pearce, P.L. (2003), Australian tourist attractions: The links between organisational characteristics and planning. Journal of Travel Research, Vol. 42(1), pp. 24-35.

Ernawati, D.B., \& Pearce, P.L. (2003), Tourism courses at the higher education level in Indonesia: The perspectives of the stakeholders. Journal of Travel and Tourism Teaching, Vol. 3(2), pp. 1-18. 
Moscardo, G., \& Pearce, P. (2003), Presenting destinations: Marketing host communities. In S. Singh, D. Timothy \& R.K. Dowling (Eds.), Tourism in destination communities (pp. 253-272). New York: CAB International.

Pearce, P.L., Morrison, A.M., \& Moscardo, G.M. (2003), Individuals as tourist icons: A developmental and marketing analysis. Journal of Hospitality \& Leisure Marketing, Vol. 10(1/2), pp. 63-86.

Pearce, P.L. (2002), The curriculum reform and trends in hospitality education in Australia. Keynote speech. In: The curriculum reform and trends of hospitality education development, Proceedings of Hospitality Education International Conference, June 7-8, 2002, Taipei, Taiwan (pp. 119141). Taipei: National Taiwan Normal University.

Ernawati, D.B., \& Pearce, P.L. (2002), Tourism courses at the higher education level in Indonesia: The perspectives of the stakeholders. In: Proceedings of First Asia Pacific Forum for Graduate Students Research in Tourism, 22 May 2002, Macao (pp. 479-490). Hong Kong: The Hong Kong Polytechnic University.

Yagi, C., \& Pearce, P.L. (2002), Tourists' preferences for seeing other tourists. In: Proceedings of First Asia Pacific Forum for Graduate Students Research in Tourism, 22 May 2002, Macao (pp. 452-466). Hong Kong: The Hong Kong Polytechnic University.

Lee, U-I., \& Pearce, P.L. (2002), Travel motivation and travel career patterns. In: Proceedings of First Asia Pacific Forum for Graduate Students Research in Tourism, 22 May 2002, Macao (pp. 17-35). Hong Kong: The Hong Kong Polytechnic University.

Lee, D., \& Pearce, P.L. (2002), Community attitudes to the acceptability of user fees in natural settings. Tourism and Hospitality Research, Vol. 4(2), pp. 158-173.

Pearce, P., Benckendorff, P., \& Johnstone, S. (2001), Chapter 7: Tourist attractions: Evolution, analysis and prospects. In: B. Faulkner, G. Moscardo \& E. Laws (Eds.), Tourism in the 21st century: Lessons from experience (pp. 110-128). London: Continuum.

Moscardo, G., Pearce, P., \& Morrison, A. (2001), Evaluating different bases for market segmentation: A comparison on geographic origin versus activity participation for generating tourist market segments. Journal of Travel \& Tourism Marketing, Vol. 10(1), pp. 29-49

Moscardo, G., Pearce, P., Green, D., \& O'Leary, J.T. (2001), Understanding coastal and marine tourism demand from three European markets: Implications for the future of ecotourism. Journal of Sustainable Tourism, Vol. 9(3), pp. 212-227.

Pearce, P.L., \& Moscardo, G. (2001), "Been already and done it before": Understanding visitors repeating trips to the Great Barrier Reef. In: C. Pforr \& B. Janeczko (Eds), CAUTHE 2001: Capitalising on Research, 
Proceedings of the eleventh Australian Tourism and Hospitality Research Conference, 7-10 February 2001 (pp. 268-280). Canberra: University of Canberra.

Pearce, P. (2001), Macro challenges for wildlife tourism development. Capitalising on Research, Conference Program. Council for Australian University Tourism and Hospitality Education (CAUTHE) 2001 National Research Conference, 7-10 February 2001 (p. 104 - Abstract). Canberra University of Canberra.

Pearce, P. (2001), Until next time: The development and potential usefulness of a repeat visitor framework. Capitalising on Research, Conference Program. Council for Australian University Tourism and Hospitality Education (CAUTHE) 2001 National Research Conference, 7-10 February 2001 (p. 105 - Abstract). Canberra: University of Canberra.

Moscardo, G., Pearce, P., Morrison, A., Green, D., \& O’Leary, J.T. (2000), Developing a typology for understanding visiting friends and relatives markets. Journal of Travel Research, Vol. 38(3), pp. 251-259

Morrison, A., Woods, B., Pearce, P., Moscardo, G., \& Sung, H.H. (2000), Marketing to the visiting friends and relatives segment: An international analysis. Journal of Vacation Marketing, Vol. 6(2), pp. 102-118.

Pearce, P.L. (2000), Entries for Achievement, Allocentric, Anticipation, Attitude, Attribution theory, Behaviour, Guided tour, Prestige, Psychographics, Psychology, Self-actualisation, Self-discovery, Theme park, Wayfinding. In: J. Jafari (Chief Ed.), Encyclopedia of Tourism. London: Routledge.

Richins, H., \& Pearce, P. (2000), Influences on tourism development decision making: Coastal local government areas in Eastern Australia. Influences on tourism development decision making: Coastal local government areas in Eastern Australia. Journal of Sustainable Tourism, Vol. 8(3), pp. 207-231.

Moscardo, G., \& Pearce, P.L. (2000), Seasonality and tropical tourism. In: B. McKellar (Ed.), Tourism: A strategic industry in Asia and Pacific: Defining problems and creating solutions. Proceedings of The Sixth Asia Pacific Tourism Association Annual Conference, June 28-July 1, 2000, Phuket, Thailand (pp. 91-100). APTA.

Moscardo, G. \& Pearce, P.L. (1999), Understanding ethnic tourists. Annals of Tourism Research, Vol. 26(2), pp. 416-434.

Pearce, P.L. (1999), Touring for pleasure: Studies of the senior self-drive travel market. Tourism Recreation Research, , Vol. 24(1), pp. 35-42.

Pearce, P.L., \& Moscardo, G. (1999), Tourism Community analysis: Asking the right questions. In: D.G. Pearce \& R.W. Butler (Eds.), Contemporary issues in tourism development. London: Routledge.

Pearce, P.L., \& Moscardo, G. (1998), The role of interpretation in influencing visitor satisfaction: A rainforest case study. In: W. Faulkner, C. Tidswell 
and D. Weaver, (Eds.), Progress in Tourism and Hospitality Research. Proceedings of the Eighth Australian Tourism and Hospitality Research Conference. Canberra: Bureau of Tourism Research.

Pearce, P.L. (1998), The relationship between residents and tourists: The research literature and management directions. In: W.F. Theobald (Ed.), Global Tourism, 2nd edn. (pp. 129-149). Oxford: Butterworth-Heinemann.

Pearce, P. (1998), Marketing and management trends in tourist attractions. Asia Pacific Journal of Tourism Research, Vol. 3(1), pp. 1-8.

Pearce, P., Kim, E., \& Lussa, S. (1998), Facilitating tourist host social interaction: An overview and assessment of the Culture Assimilator. In: E. Laws, G. Moscardo, \& B. Faulkner, Embracing and managing change in tourism: International case studies. London: Routledge.

Pearce, P. (1997), Tourism market segments and travel psychology. In: C.Y. Gee \& E. Fayos-Solá (Eds.), International tourism: A global perspective (pp. 137-153). Madrid, Spain: World Tourism Organization.

Moscardo, G., \& Pearce, P. (1997), Social and cultural aspects of tourism. In: C.Y. Gee \& E. Fayos-Solá (Eds.), International tourism: A global perspective (pp. 231-248). Madrid, Spain: World Tourism Organization.

Moscardo, G., Pearce, P., Woods, B., Murphy, L., \& Ross, G. (1997), Quality reef tourism: Building a web of strategic knowledge. In: D. Wachenfeld, J. Oliver, \& K Davis (Eds.), State of the Great Barrier Reef World Heritage Area Workshop: Proceedings of a technical workshop held in Townsville, Queensland, Australia, 27-29 November 1995, Workshop Series No. 23. Townsville: Great Barrier Reef Marine Park Authority.

Kim, Y.J. Edward, \& Pearce, P.L. (1997), The international significance of tourism studies. Journal of Tourism Sciences, Vol. 21(1), pp. 268-277.

Moscardo, G., Woods, B., \& Pearce, P. (1997), Evaluating the effectiveness of pictorial symbols in reef visitor education. CRC Reef Research Centre Technical Report No. 15. Townsville: CRC Reef Research Centre.

Pearce, P., \& Black, N. (1996), The simulation of tourist environments: Methodological perspectives for enhancing tourism research. In: G. Prosser (Ed.), Tourism \& Hospitality Research: Australian and International Perspectives. Proceedings from the Australian Tourism and Hospitality Research Conference, Coffs Harbour (pp. 419-425). Canberra: Bureau of Tourism Research.

Pearce, P.L., \& Fagence, M. (1996), The legacy of Kevin Lynch: Research implications. Annals of Tourism Research, Vol. (23)3, pp. 576-598.

Pearce, P.L. (1996), Recent research in tourist behaviour. Asia Pacific Journal of Tourism Research, 1(1), 7-17.

Moscardo, G., Morrison, A.M., Pearce, P.L., Lang, C-T., \& O’Leary, J.T. (1996). Understanding vacation destination choice through travel motivation and activities. Journal of Vacation Marketing, Vol. 2(2), pp. 109-122. 
Moscardo, G., Morrison, A.M., \& Pearce, P.L. (1996), Specialist accommodation and ecologically-sustainable tourism. Journal of Sustainable Tourism, Vol. 4(1), pp. 29-52.

Morrison, A., Pearce, P., Moscardo, G., Nadkarni, N., \& O’Leary, J. (1996), Specialist accommodation: Definition, markets served, and roles in tourism development. Journal of Travel Research, Vol. 35(1), pp. 18-26.

Kim, Y.J. (Edward), Pearce, P.L., Morrison, A.M., \& O’Leary, J.T. (1996), Mature vs. youth travelers: The Korean market. Asia Pacific Journal of Tourism Research, Vol. 1(1), pp. 102-112.

Pearce, P.L. (1995), Chapter 9: Pleasure travel motivation. In: R.W. McIntosh, C.R. Goeldner \& J.R. Brent Ritchie, Tourism: Principles, practices, philosophies (7th edition), (pp. 167-190). New York: John Wiley.

Pearce, P.L. (1995), From culture shock and culture arrogance to culture exchange: Ideas towards sustainable socio-cultural tourism. Journal of Sustainable Tourism, Vol. 3(3), pp. 143-154.

Loker-Murphy, L., \& Pearce, P.L. (1995), Young budget travelers: Backpackers in Australia. Annals of Tourism Research, Vol. 22(4), pp. 819-843.

Law, J., Pearce, P.L., \& Woods, B.A. (1995), Stress and coping in tourist attraction employees. Tourism Management, Vol. 16(4), pp. 277-284.

Pearce, P.L., \& Mudjiman, H. (1995), Asia Pacific Region cooperation in tourism education and training. A case study of the University Sebelas Maret and James Cook University Partnership Potential. In: T. Sofield and M.S.S. Tarjana (Eds), A profile of Javanese culture (pp. 1-8). Townsville: James Cook University.

Moscardo, G., Rutledge, J., \& Pearce, P.L. (1995), Expanding management education: Creativity, cultural awareness and cognitive skills. In: Bureau of Tourism Research, Tourism Research and Education in Australia, Proceedings from the Tourism and Educators Conference, Gold Coast (1994) (pp. 321-330). Canberra: Bureau of Tourism Research.

Black, N., \& Pearce, P.L. (1995), Maps for tourists: An exploration of function and form. In Bureau of Tourism Research, Tourism Research and Education in Australia, Proceedings from the Tourism and Educators Conference, Gold Coast (1994) (pp. 285-298). Canberra: Bureau of Tourism Research.

Faulkner, B., Pearce, P., Shaw, R., \& Weiler, B. (1995), Tourism research in Australia: Confronting the challenges of the 1990's and beyond. In: Bureau of Tourism Research, Tourism Research and Education in Australia, Proceedings from the Tourism and Educators Conference, Gold Coast (1994) (pp. 3-25). Canberra: Bureau of Tourism Research.

Pearce, P.L. (1995), Issues in Australian tourism research. World Tourism Trends to the Year 2000: Research Catalyst Workshop, 14-15 May 1993, UWS Hawkesbury. Sydney: University of Western Sydney. 
Pearce, P.L., \& Rutledge, J.L. (1994), Architectural design and planning of tourist facilities: Theme park planning and design. Proceedings of the Environments for Tourism Conference. In: Roehl, W.S. (Ed.), Proceedings of the Environments for Tourism Conference (pp. 320-350). Las Vegas, Nevada: William F. Harrah College of Hotel Administration, University of Nevada, Las Vegas.

Pearce, P.L. (1994), Keynote Address: Tourism and interpretation: Beyond talented optimism. In: K. Maxwell \& S. Muloin (Eds.) (1994) Embracing interpretation in the year of indigenous peoples. Open to Interpretation 1993: Conference papers of the annual conference of the Interpretation Australia Association, 29 November - 1 December, Newcastle, Australia. Callaghan, NSW: The University of Newcastle.

Pearce, P.L. (1994), Tourism-resident impacts: Examples, explanations and emerging solutions. In: Theobald, W.F. (Ed.), Global tourism: The next decade. Oxford: Butterworth-Heinemann. (pp. 128-154).

Cameron, S., Pearce, P., \& Phelps, J. (1994), Examining Queensland's regional tourist authorities - an initial organisational analysis. In: A. Layton (Ed.) Queensland Economic Forecasts and Business Review, March (pp.71-86). Qld.: Queensland University of Technology.

Pearce, P., \& Fenton, M. (1994), Multidimensional scaling and tourism research. In: J.R. Brent Richie \& C.R. Goeldner (Eds.) Travel, tourism, and hospitality research: A handbook for managers and researchers (pp.523-532). New York: John Wiley \& Sons, Inc.

Pearce, P.L. (1993). Defining tourism as a specialism: A justification and implications. Teoros International, Vol. 1(1), pp. 25-32.

Pearce, P.L. (1993), The psychology of tourism. In Khan, M, Olsen, M. \& Var, T. VNR's Encyclopedia of Hospitality and Tourism, pp. 873-883. Florence, KY: Van Nostrand Reinhold.

Pearce, P.L. (1993). From culture shock to culture exchange: The agenda for human resource development in cross-cultural interaction. In R. De Alwis, G. Ardika \& A. Yeo (Eds.) Global action to global challenge. A PATA/WTO Human Resources for Tourism Conference, 4-6 October 1993. Singapore: PATA.

Pearce, P.L. (1993), The importance, incidence and interpretation of the social impacts of Australian Tourism. In: B Faulkner \& M Kennedy (Eds), Australian Tourism Outlook Forum 1992: Contributed papers. Canberra: Bureau of Tourism Research.

Pearce, P.L. \& Moscardo, G.M. (1992), The boutique-specialist accommodation sector: Perceived Government needs and policy initiatives. Queensland Small Business Research Journal, pp. 34-41.

Fielding, K., Pearce, P.L. \& Hughes, K. (1992), Climbing Ayers Rock: Relating motivation, time perception and enjoyment. Journal of Tourism Studies, Vol. 3(2), pp. 49-57. 
Pearce, P. (1992) Review of Tourism. In Australian Science and Technology Council Research and Technology in Tropical Australia Symposia. Occasional Paper No. 23, November 1992 (pp. 73-84). Canberra: AGPS. Pearce, P.L. (1992), Fundamentals of tourist motivation. In: D. Pearce and R. Butler (Eds.), Tourism research: Critiques and challenges (pp. 85105). London: Routledge and Kegan Paul.

Pearce, P.L. \& Sofield, T.H.B. (1991), The universal versus the specific debate in tourism education. Proceedings of the 1990 National Conference on Tourism Education. Canberra: Bureau of Tourism Research. $12 \mathrm{pp}$.

Pearce, P.L. (1991), Locating tourism studies in the landscape of knowledge. In: R.D. Bratton, F.M. Go \& J.R. Brent Ritchie (Eds), New Horizons in Tourism and Hospitality Education, Training and Research: Conference Proceedings, Calgary, Canada, July 2-5, 1991 (pp.297-302). Calgary: World Tourism Education and Research Centre, The University of Calgary.

Pearce, P.L. \& Stringer, P.F. (1991). Psychology and tourism. Annals of Tourism Research, Vol. 18(1), pp. 136-154.

Pearce, P.L. (1991), Designing for distinctiveness - Variety in the British Visitor Centre. In: G Moscardo \& K Hughes (Eds.). In Visitor Centres: Exploring New Territory. (pp. 138-143). Townsville: Department of Tourism, James Cook University.

Pearce, P.L. (1991), Visitor centres and their functions in the landscape of tourism. In: G. Moscardo \& K Hughes (Eds.)Visitor Centres: Exploring New Territory. (pp. 7-14). Townsville: Department of Tourism, James Cook University.

Pearce, P.L. (1991), Travel stories: An analysis of self-disclosure in terms of story structure, valence, and audience characteristics. Australian Psychologist, Vol. 26, 3, pp. 172-174.

Pearce, P.L., Moscardo, G. \& Ross, G.F. (1991), Tourism impact and community perceptions: An equity-social representational perspective. Australian Psychologist, Vol. 26(3), pp. 147-152.

Pearce, P.L. (1991), Introduction: The tourism psychology conversation. Australian Psychologist, Vol. 26(3), pp. 145-146.

Pearce, P.L. (1991), Analysing tourist attractions, Journal of Tourism Studies, Vol. 2(1), pp. 46-55.

Pearce, P.L. (1991). Towards the better management of tourist queues. In: Medlik, S., Managing tourism (pp. 215-223). Oxford: Butterworth-Heinemann.

Pearce, P.L. (1990). Farm tourism in New Zealand: A social situation analysis, Annals of Tourism Research, Vol. 17(3), pp. 337-352.

Pearce, P.L. \& James, M.K. (1990), Community and visitor reactions to tourism infrastructure in the Great Reef Region. In Proceedings of the 4th 
Pacific Congress on Marine Science and Technology, PACON 90, Tokyo, July 16-20, 1990, Volume 2 (pp. 374-379).

Pearce, P.L. (1990), Trends in tourism behaviour, Australian Tourism Outlook Proceedings 1990: Contributed papers. Canberra: Bureau of Tourism Research.

Moscardo, G.M., \& Pearce, P.L. (1989), Ethnic tourism a visitor perspective. Proceedings of the Tourist and Travel Research Association Conference, Hawaii, June 1989.

Pearce, P.L., \& Moscardo, G.M. (1989), The structure of tourist activities for regions (The STAR system). Proceedings of the Tourist and Travel Research Association Conference, Hawaii, June 1989.

Pearce, P.L. (1989), Social impacts of tourism. In The social, cultural and environmental impacts of tourism (pp. 1-39). Sydney: NSW Tourism Commission

Pearce, P.L. (1989), Vacationing. In P. Marsh (Ed), Lifestyle (pp. 1-45). Oxford: Andromeda Press.

Moscardo, G.M., \& Pearce, P.L. (1988), Tourism and reviving dying towns. Heritage Communicator, Vol. 4, pp. 5-8.

Dann, G., Nash, D., \& Pearce, P.L. (1988), Methodology in tourism research. Annals of Tourism Research, Vol. 15, pp. 1-28.

Fenton, M., \& Pearce, P.L. (1987), Multidimensional scaling and tourism research. Annals of Tourism Research, Vol. 15, pp. 236-254.

Pearce, P.L. (1986), Tourism developments: An Australian view. Annals of Tourism Research, Vol. 13, pp. 670-673.

Pearce, P.L. (1986), Museums and the tourist experience: An Australian perspective. Annals of Tourism Research, Vol.13, pp. 659-666.

Moscardo, G.M., \& Pearce, P.L. (1986), Evaluation in museums. Melbourne: Museums Association of Australia, Victorian Branch. p.p. 30.

Moscardo, G.M., \& Pearce, P.L. (1986), Historical theme parks: An Australian experience in authenticity. Annals of Tourism Research, Vol. 13, pp. 467-479.

Pearce, P.L., \& Moscardo, G.M. (1986), The concept of authenticity in tourists' experiences. Australian and New Zealand Journal of Sociology, Vol. 22, pp. 121-132.

Moscardo, G.M., \& Pearce, P.L. (1986), Visitor centres and environmental interpretation; an exploration of the relationships among visitor enjoyment, understanding and mindfulness. Journal of Environmental Psychology, Vol. 6, pp. 89-108.

Pearce, P.L. (1985), A systematic comparison of travel related roles. Human Relations, Vol. 38, pp. 1001-1011.

Pearce, P.L., \& Moscardo, G.M. (1985), Tourist theme parks: Research practices and possibilities. Australian Psychologist, Vol. 20, pp. 303312 . 
Pearce, P.L., \& Moscardo, G.M. (1985), The relationship between travellers' career levels and the concept of autheniticity. Australian Journal of Psychology, Vol. 37, pp. 157-174.

Pearce, P.L., \& Moscardo, G.M. (1985), Visitor evaluation: An appraisal of goals and techniques. Evaluation Review, Vol. 9, pp. 281-306.

Pearce, P.L., \& Moscardo, G.M. (1984), Making sense of tourists' complaints. International Journal of Tourism Management, Vol. 5, pp. 20-23.

Pearce, P.L., \& Promnitz, J. (1984), Research for tourist highways. Australian Road Research, Vol. 14, pp. 156-160.

Pearce, P.L., \& Black, N. (1984), Dimensions of national park maps: A psychological evaluation. Cartography, Vol. 13, pp. 189-203.

Stringer, P., \& Pearce, P.L. (1984), Toward a symbiosis of social psychology and tourism studies. Annals of Tourism Research, Vol. 11, pp. 5-7.

Pearce, P.L. (1984), Tourist-guide interaction. Annals of Tourism Research, Vol. 11, pp. 129-146.

Pearce, P.L. (1984), Some sociological considerations relating to human perception and recreational use of coastal ecosystems. In: J.D.S. Davie, J.R. Hanley \& B.C. Russell (Eds.), Coastal Management in Northern Australia (pp. 35-38). Darwin: ANU North Australian Research Unit.

Pearce, P.L., \& Caltabiano, M.L. (1983), Inferring travel motivation from travellers' experiences. Journal of Travel Research, Vol. XXII, pp. 1620.

Pearce, P.L. (1983), Fun, sun and behaviour: Social psychologists and the tourist industry. Australian Psychologist, Vol. 18, pp. 89-95.

Pearce, P.L. (1982), Perceived changes in holiday destinations. Annals of Tourism Research, Vol. 9, pp. 145-164.

Pearce, P.L., \& Caltabiano, N.J. (1982), Gesture decoding and encoding in children: The effects of ethnicity, age and sex. Australian Journal of Psychology, Vol. 34, pp. 17-24.

Pearce, P.L. (1982), Tourists and their hosts: Some social and psychological effects of intercultural contact. In S. Bochner (Ed.), Cultures in Contact. Oxford: Pergamon.

Pearce, P.L., \& Promnitz, J. (1982), Road side rest areas: Studies from two Australian states. Australian Road Research, Vol. 12, pp. 29-40.

Pearce, P.L., Innes, J.M., O’Driscoll, P., \& Morse, S.J. (1981), Stereotyped images of Australian cities. Australian Journal of Psychology, Vol. 33, pp. 29-39.

Pearce, P.L. (1981), Route maps: A study of travellers' perception of a section of countryside. Journal of Environmental Psychology, Vol. 1, pp. 141-155.

Pearce, P.L. (1981), Environment shock: A study of tourists' reactions to two tropical islands. Journal of Applied Social Psychology, Vol. 11, pp. 268-283. 
Pearce, P.L., \& Amato, P. (1980), A taxonomy of helping: A multidimensional scaling analysis. Social Psychology Quarterly, Vol. 43, pp. 363-371.

Pearce, P.L. (1980), Tourism's human conflicts: Towards a more psychological approach. Annals of Tourism Research, Vol. VII, pp. 122-126.

Pearce, P.L., \& Cairney, P. (1980), Recognizing city scenes: A test of Milgram's formula. International Journal of Psychology, Vol. 15, pp. 95103.

Pearce, P.L. (1980), A favourability-satisfaction model of tourist's evaluations. Journal of Travel Research, Vol. XIX, pp. 13-17.

Pearce, P.L. (1980), Strangers, travellers and greyhound terminals: A study of small scale helping behaviours. Journal of Personality and Social Psychology, Vol. 38, pp. 935-940.

Mann, L., \& Pearce, P.L. (1978), The social psychology of the sports spectator. In: D. Glencross (Ed.), Sport in Australia, pp. 177-201, Sydney, Macmillan.

Pearce, P.L. (1977), Mental Souvenirs: A study of tourist and their city maps. Australian Journal of Psychology, Vol. 29, pp. 203-210.

\section{CONFERENCE PAPERS, REPORTS AND PRESENTATIONS (not published)}

Pearce, P.L., Murphy, L. \& Brymer, E. (2009), Evolution of the backpacker market and the potential for Australian Tourism. Australian Backpacker Industry Conference. Sydney November 2009.

Pearce, P.L. (2009), Visitor Centres and the Burdekin Shire, Burdekin Shire Council, Ayr, Queensland.

Pearce, P.L. (2009), New directions in the tourism youth market, North Queensland Economic Development Forum, Townsville October 2009.

Pearce, P.L. (2007), The relationship between positive psychology and tourist behaviour studies. International Academy for the Study of Tourism conference. Mugla, Turkey May 2007.

Pearce, P.L. (2007), Understanding attitudes developed through person to person contact. International conference on Tourism and Politics, Hebrew University of Jerusalem. May 2007.

Pearce, P.L. (2007), Local applications of global tourism trends. Cross Cultural Collaboration in Hospitality and related services. Synergies and Future Possibilities. Symposium Cairns October 2007, pp.1-16.

Pearce, P.L. (2006), Global tourism trends and tour guiding performance. November. Second International Forum on Tourism and Hospitality. Singapore

Pearce, P.L. (2005), Teaching tourism (and related areas) better: Steps towards achieving improved educator performance. Keynote Speech: ASAHIL Conference, Phuket, Thailand, October 2005. 
Pearce, P.L. (2005). Sustainability research and backpacker studies; Intersections and mutual insights. Keynote Speech: ATLAS Backpacker Conference, Bangkok, Thailand, September 1-3, 2005.

Pearce, P.L. (2005), Tourism Development: Principles from practice in peripheral and provincial areas. Keynote Speech: 'New tourism for Asia-Pacific', The 11th APTA Conference, Koyang, Korea, 7-10 July 2005.

Pearce, P.L. (2005), Entertainment science and new directions for tourism research. Paper prepared for the International Academy for the Study of Tourism Meeting, Beijing, China, July 2005.

Pearce, P.L. (2004), Visitor centres: New trends, new futures. Third National Conference on Tourism Futures: Wealth creating, growth sustaining, Townsville, 4-7 August 2004 (pp. 16). Townsville: Tourism Queensland.

Richards, F., \& Pearce, P. (2000), Public perceptions and understandings In Book of Abstracts, Ecotourism - Changing the Nature of Australia, Ecotourism Association of Australia $8^{\text {th }}$ national Conference, 2-5 November 2000, Lorne and Phillip Island, Victoria (p. 27 - Abstract).

Moscardo, G., Greenwood, T., Johnstone, S., \& Pearce, P. (2000), Researching GBR visitors: Getting serious about fun. In CRC Reef Research Centre, Research days: Our Reef - Our Future. Abstracts and Conference Program, 28-29 September 2000.

Pearce, P. (2000), Visitor satisfaction: Issues and benchmarking. In Rainforest CRC Rainforest Partnerships 2000, Conference Compendium: The Annual Conference of the Rainforest CRC, 16-17 November 2000 (p. 19 - Abstract).

Pearce, P.L. (1995), Building the study of tourism in the Asia Pacific. In Building a cooperative tourism system among north-east countries in upcoming year 2000. The International Tourism Seminar, Seoul, 26 September 1995 (pp. 11-20). Korea: The College of Tourism Sciences, Kyonggi University. 


\section{List of publications by Professor Ph. L. Pearce generated by the SCOPUS for the period 2011-2020 (accessed on 31/05/2021) ${ }^{2}$}

\section{1}

Pearce P.L. (2011), Respecting the Past, Preparing for The Future; the Rise of Australian Academic Tourism Research. [in:] Alejziak W. (ed.), "Folia Turistica" - "The Master Classes": Special Edition Published on the 35 Anniversary of the Tourism and Recreation Faculty at the University School of Physical Education in Kraków, Vol. 25(1), pp. 187-205. Online: http://www.folia-turistica.pl/attachments/article/402/FT_25(1)_2011.pdf

Pearce P.L. (2011), Szacunek dla przeszłości przygotowaniem na przyszłość - rozwój australijskich badań akademickich nad turystyką (in Polish), [in:] Alejziak W. (ed.) "Folia Turistica” - „Z warsztatów „Mistrzów”. Folia Turistica: Wydanie specjalne z okazji 35-lecia Wydziału Turystyki i Rekreacji AWF w Krakowie, Nr 25(2), pp. 207- 229. Online: http:// www.folia-turistica.pl/attachments/article/402/FT_25(2)_2011.pdf

Jin, Q., \& Pearce, P. (2011), Tourist perception of crowding and management approaches at tourism sites in Xi'an. Asia Pacific Journal of Tourism Research, 16(3), 325-338. doi:10.1080/10941665.2011.572667.

Jin, Q., \& Pearce, P.L. (2011), Actual use levels and perceived crowding in the peak season at tourist sites in Xi'an. Journal of China Tourism Research, Vol. 7(3), pp. 263-281. doi:10.1080/19388160.2011.599241.

Murphy, L., Moscardo, G., Benckendorff, P., \& Pearce, P. (2011), Evaluating tourist satisfaction with the retail experience in a typical tourist shopping village. Journal of Retailing and Consumer Services, Vol.18(4), pp. 302-310. doi:10.1016/j.jretconser.2011.02.004.

Pearce, P., Filep, S., \& Ross, G. (2011), Tourists tourism and the good life. Tourists tourism and the good life (pp. 1-226) doi:10.4324/9780203845868 Retrieved from www.scopus.com.

Pearce, P.L. (2011), Tourist behaviour and the contemporary world. Tourist behaviour and the contemporary world (pp. 1-189) Retrieved from www.scopus.com.

Pearce, P.L. (2011), Tourist scams: Exploring the dimensions of an international tourism phenomenon. European Journal of Tourism Research, Vol. 4(2), pp. 147-156. Retrieved from www.scopus.com.

${ }^{2}$ In preparing the list detailed verification did not take place (for example checking and adding page numbers for given articles in the works cited was not performed). The only filter applied for all items on the list was whether P. L. Pearce was one of the authors, resulting in two items being removed from the initial list. 
Pearce, P.L. (2011), Travel motivation, benefits and constraints to destinations. Destination marketing and management: Theories and applications (pp. 39-52) Retrieved from www.scopus.com.

\section{2}

Chen, T., \& Pearce, P.L. (2012), Research note: Seasonality patterns in Asian tourism. Tourism Economics, 18(5), 1105-1115. doi:10.5367/ te.2012.0163.

Cohen, E., Olsen, K., \& Pearce, P.L. (2012), The dilemma of authenticity and inauthenticity. Critical debates in tourism (pp. 249-276) Retrieved from www.scopus.com.

Loi, K. I., \& Pearce, P.L. (2012), Annoying tourist behaviors: Perspectives of hosts and tourists in Macao. Journal of China Tourism Research, Vol. 8(4), pp. 395-416. doi:10.1080/19388160.2012.729411.

Loi, K. -., \& Pearce, P.L. (2012), Powerful stakeholders' views of entertainment in Macao's future. Journal of Business Research, Vol. 65(1), pp. 4-12. doi:10.1016/j.jbusres.2011.07.008.

Pearce, P.L. (2012), Australian tourism education: The quest for status. Global tourism higher education: Past, present, and future (pp. 251267) doi:10.1300/J172v05n03_11 Retrieved from www.scopus.com.

Pearce, P.L. (2012), Relationships and the tourism experience: Challenges for quality-of-life assessments. Handbook of tourism and quality-of-life research: Enhancing the lives of tourists and residents of host communities (pp. 9-29) doi:10.1007/978-94-007-2288-0_2 Retrieved from www. scopus.com.

Pearce, P.L. (2012), The experience of visiting home and familiar places. Annals of Tourism Research, Vol. 39(2), pp. 1024-1047. doi:10.1016/j. annals.2011.11.018.

Pearce, P.L. (2012), The role of relationships in the tourist experience. Global tourism: Third edition (pp. 103-122) Retrieved from www.scopus.com.

Pearce, P.L. (2012), Tourists' written reactions to poverty in Southern Africa. Journal of Travel Research, Vol. 51(2), pp. 154-165. doi:10.1177/0047287510396098.

Pearce, P.L., \& Chen, T. (2012), Citizens' representations of China's golden weeks. Asia Pacific Journal of Tourism Research, Vol. 17(4), pp. 394415. doi:10.1080/10941665.2011.628331.

Scarinci, J., \& Pearce, P. (2012), The perceived influence of travel experiences on learning generic skills. Tourism Management, Vol. 33(2), pp. 380-386. doi:10.1016/j.tourman.2011.04.007. 
Wu, M. -., \& Pearce, P. (2012), Looking down, looking out and looking forward: Tibetan youth view tourism in the future. The host gaze in global tourism (pp. 125-141) Retrieved from www.scopus.com.

Wu, M. -., \& Pearce, P.L. (2012), Tourism research in and about Tibet: Employing a system for reviewing regional tourism studies. Tourism and Hospitality Research, Vol. 12(2), pp. 59-72. doi:10.1177/1467358411434973.

\section{3}

Filep, S., \& Pearce, P. (2013), A blueprint for tourist experience and fulfilment research. Tourist experience and fulfilment: Insights from positive psychology (pp. 223-232) doi:10.4324/9780203134580 Retrieved from www.scopus.com.

Filep, S., \& Pearce, P. (2013), Introducing tourist experience and fulfilment research. Tourist Experience and Fulfilment: Insights from Positive Psychology, pp. 1-14. doi:10.4324/9780203134580.

Filep, S., \& Pearce, P. (2013), Tourist experience and fulfilment: Insights from positive psychology. Tourist experience and fulfilment: Insights from positive psychology (pp. 1-241) doi:10.4324/9780203134580 Retrieved from www.scopus.com.

Pearce, P., \& Benckendorff, P. (2013), Benchmarking, usable knowledge and tourist attractions. Knowledge sharing and quality assurance in hospitality and tourism (pp. 29-52) doi:10.1300/J162v07n01_03 Retrieved from www.scopus.com.

Pearce, P., \& Pabel, A. (2013), Humour, tourism and positive psychology. Tourist experience and fulfilment: Insights from positive psychology (pp. 17-36) doi:10.4324/9780203134580 Retrieved from www.scopus. com.

Pearce, P.L. (2013), Australian music and Aussie team sports: How the experience economy and the score interact. Music business and the experience economy: The Australasian case (pp. 175-188) doi:10.1007/978-3642-27898-3_11 Retrieved from www.scopus.com.

Pearce, P.L. (2013), From discord to harmony: Connecting Australian music and business through the experience economy. Music business and the experience economy: The Australasian case (pp. 1-9) doi:10.1007/978-3642-27898-3_1 Retrieved from www.scopus.com.

Pearce, P.L., \& Packer, J. (2013), Minds on the move: New links from psychology to tourism. Annals of Tourism Research, Vol. 40(1), pp. 386411. doi:10.1016/j.annals.2012.10.002.

Pearce, P.L., Wu, M. -., De Carlo, M., \& Rossi, A. (2013), Contemporary experiences of Chinese tourists in Italy: An on-site analysis in Milan. Tourism Management Perspectives, Vol. 7, pp. 34-37. doi:10.1016/j. tmp.2013.04.001. 
Pearce, P.L., Wu, M. -., \& Osmond, A. (2013), Puzzles in understanding Chinese tourist behaviour: Towards a triple-C gaze. Tourism Recreation Research, Vol. 38(2), pp. 145-157. doi:10.1080/02508281.2013.11081741.

Tschmuck, P., Campbell, S., \& Pearce, P.L. (2013), Music business and the experience economy: The Australasian case. Music business and the experience economy: The Australasian case (pp. 1-229) doi:10.1007/978-3642-27898-3 Retrieved from www.scopus.com.

Tschmuck, P., Campbell, S., \& Pearce, P. L. (2013), Preface. Music Business and the Experience Economy: The Australasian Case, , v-vi. doi:10.1007/978-3-642-27898-3.

Wu, M. -., \& Pearce, P.L. (2013), Tourists to Lhasa, Tibet: How local youth classify, understand and respond to different types of travelers. Asia Pacific Journal of Tourism Research, Vol. 18(6), pp. 549-572. doi:10.1080/ 10941665.2012.680975.

\section{4}

Hay, R., \& Pearce, P. (2014), Technology adoption by rural women in Queensland, Australia: Women driving technology from the homestead for the paddock. Journal of Rural Studies, 36, 318-327. doi:10.1016/j. jrurstud.2014.10.002.

Pearce, P.L. (2014), Cricketers as tourists; analyses of culture shock, travel motivation and learning. Tourism and cricket: Travels to the boundary (pp. 103-119) Retrieved from www.scopus.com.

Wu, M. -., \& Pearce, P.L. (2014), Appraising netnography: Towards insights about new markets in the digital tourist era. Current Issues in Tourism, Vol. 17(5), pp. 463-474. doi:10.1080/13683500.2013.833179.

Wu, M. -., \& Pearce, P.L. (2014), Asset-based community development as applied to tourism in Tibet. Tourism Geographies, Vol. 16(3), pp. 438456. doi:10.1080/14616688.2013.824502.

Wu, M. -., \& Pearce, P.L. (2014), Chinese recreational vehicle users in Australia: A netnographic study of tourist motivation. Tourism Management, Vol. 43, pp. 22-35. doi:10.1016/j.tourman.2014.01.010.

Wu, M. -., \& Pearce, P.L. (2014), Host tourism aspirations as a point of departure for the sustainable livelihoods approach. Journal of Sustainable Tourism, Vol. 22(3), pp. 440-460. doi:10.1080/09669582.2013.839689.

Wu, M. -., Wall, G., \& Pearce, P. L. (2014), Shopping experiences: International tourists in Beijing's silk market. Tourism Management, Vol. 41, pp. 96-106. doi:10.1016/j.tourman.2013.09.010.

Zhou, L., Ye, S., Pearce, P.L., \& Wu, M. -. (2014), Refreshing hotel satisfaction studies by reconfiguring customer review data. International Journal of Hospitality Management, Vol. 38, pp. 1-10. doi:10.1016/j. ijhm.2013.12.004. 


\section{5}

Loi, K. I., \& Pearce, P.L. (2015), Exploring perceived tensions arising from tourist behaviors in a Chinese context. Journal of Travel and Tourism Marketing, Vol. 32(1-2), pp. 65-79. doi:10.1080/10548408.2014.986013.

Osmond, A. M., Chen, T., \& Pearce, P.L. (2015), Examining experience economy approaches to tourists' anticipated experiences: Mainland Chinese travellers consider Australia. European Journal of Tourism Research, Vol. 10, pp. 95-108. Retrieved from www.scopus.com.

Pabel, A., \& Pearce, P.L. (2015), Highlighting the benefits of tourism humour: The views of tourists. Tourism Management Perspectives, Vol. 16, pp. 357-364. doi:10.1016/j.tmp.2015.10.002.

Pearce, P.L., \& Wu, M. -. (2015). Soft infrastructure at tourism sites: Identifying key issues for Asian tourism from case studies. Tourism Recreation Research, Vol. 40(1), pp. 120-132. doi:10.1080/02508281.2015.10 10361.

Pearce, P.L., Wu, M. -., \& Chen, T. (2015), The spectacular and the mundane: Chinese tourists' online representations of an iconic landscape journey. Journal of Destination Marketing and Management, Vol. 4(1), pp. 24-35. doi:10.1016/j.jdmm.2014.11.001.

Wu, M. -., Pearce, P., Huang, K., \& Fan, T. (2015), 'Gap year' in china: Views from the participants and implications for the future. Current Issues in Tourism, Vol. 18(2), pp. 158-174. doi:10.1080/13683500.2014. 946478.

\section{6}

Bhati, A., \& Pearce, P. (2016), Vandalism and tourism settings: An integrative review. Tourism Management, Vol. 57, pp. 91-105. doi:10.1016/j. tourman.2016.05.005.

Coca-Stefaniak, A., Morrison, A. M., Edwards, D., Graburn, N., Liu, C., Pearce, P., . . . Du, G. (2016), Editorial. International Journal of Tourism Cities, Vol. 2(4), pp. 273-280. doi:10.1108/IJTC-10-2016-0041.

Kanlayanasukho, V., \& Pearce, P.L. (2016), Thai tourists on tour:The practice of designing successful tours doi:10.1108/S2042-144320160000007008 Retrieved from www.scopus.com.

Li, J., \& Pearce, P. (2016), Tourist scams in the city: Challenges for domestic travellers in urban China. International Journal of Tourism Cities, Vol. 2(4), pp. 294-308. doi:10.1108/IJTC-09-2016-0024.

Li, J., Pearce, P.L., Morrison, A. M., \& Wu, B. (2016), Up in smoke? the impact of smog on risk perception and satisfaction of international tourists in Beijing. International Journal of Tourism Research, Vol. 18(4), pp. 373-386. doi:10.1002/jtr.2055. 
Lu, H., \& Pearce, P.L. (2016), Learning by and learning from outbound Chinese group tourists doi:10.1108/S2042-144320160000007006 Retrieved from www.scopus.com.

Oktadiana, H., Pearce, P.L., \& Chon, K. (2016), Muslim travellers' needs: What don't we know? Tourism Management Perspectives, Vol. 20, pp. 124-130. doi:10.1016/j.tmp.2016.08.004.

Pabel, A., \& Pearce, P.L. (2016), Tourists' responses to humour. Annals of Tourism Research, 57, 190-205. doi:10.1016/j.annals.2015.12.018.

Pearce, P.L. (2016), Australian contributions to tourist behaviour studies. Journal of Hospitality and Tourism Management, Vol. 26, pp. 84-90. doi:10.1016/j.jhtm.2016.01.004.

Pearce, P.L. (2016), Foreword. Positive Tourism, , xi-xii. doi:10.4324/9781315707129.

Pearce, P.L., \& Deery, M. (2016), Australian contributions - papers from CAUTHE fellows. Journal of Hospitality and Tourism Management, Vol. 26, pp. 82-83. doi:10.1016/j.jhtm.2016.01.001.

Pearce, P.L., \& Wu, M. -. (2016), Conclusion: Theoretical and managerial considerations doi:10.1108/S2042-144320160000007019 Retrieved from www.scopus.com.

Pearce, P.L., \& Thanksooks, J. (2016), Towards the future of the domestic hotel in Thailand: A timeline approach. Journal of Vacation Marketing, Vol. 22(3), pp. 199-211. doi:10.1177/1356766715615915.

Pearce, P.L., \& Wu, M. -. (2016), Introduction: Meeting Asian tourists doi:10.1108/S2042-144320160000007001 Retrieved from www.scopus. com.

Pearce, P.L., \& Wu, M. -. (2016), Tourists' evaluation of a romantic themed attraction: Expressive and instrumental issues. Journal of Travel Research, Vol. 55(2), pp. 220-232. doi:10.1177/0047287514538838.

Wu, M. -., \& Pearce, P.L. (2016), Italian cathedrals and Chinese tourists: Management implications doi:10.1108/S2042-144320160000007020 Retrieved from www.scopus.com.

Wu, M. -., \& Pearce, P.L. (2016), Tourism blogging motivations: Why do Chinese tourists create little "Lonely planets"? Journal of Travel Research, Vol. 55(4), pp. 537-549. doi:10.1177/0047287514553057.

Yagi, C., \& Pearce, P.L. (2016), Imagination, anime and Japanese tourists abroad doi:10.1108/S2042-144320160000007016 Retrieved from www. scopus.com.

Zhang, C. X., \& Pearce, P.L. (2016), Experiencing Englishness: Humour and guided tours. Tourism Recreation Research, Vol. 41(3), pp. 259-271. doi:10.1080/02508281.2016.1188486. 


\section{7}

Bhati, A., \& Pearce, P. (2017), Tourist attractions in Bangkok and Singapore; linking vandalism and setting characteristics. Tourism Management, Vol. 63, pp. 15-30.

doi:10.1016/j.tourman.2017.05.014.

Huang, K., Pearce, P., \& Wen, J. (2017), Tourists' attitudes toward religious commercialization. Tourism, Culture and Communication, Vol. 17(4), pp. 259-270. doi:10.3727/109830417X15072926259397.

Moscardo, G., \& Pearce, P.L. (2017), Understanding ethnic tourists. Managing heritage and cultural tourism resources: Critical essays, Volume one (pp. 303-322). doi:10.4324/9781315249933-29 Retrieved from www. scopus.com.

Moscardo, G. M., \& Pearce, P.L. (2017),, Historic theme parks an Australian experience in authenticity. The political nature of cultural heritage and tourism: Critical essays, volume three (pp. 359-371) doi:10.4324/9781315237749-20 Retrieved from www.scopus.com.

Oktadiana, H., \& Pearce, P.L. (2017), The "bule" paradox in Indonesian tourism research: Issues and prospects. Asia Pacific Journal of Tourism Research, Vol. 22(11), pp. 1099-1109. doi:10.1080/10941665.2017.1374987.

Oktadiana, H., \& Pearce, P.L. (2017), The 26th CAUTHE annual conference 2016: 8-11 february 2016, Sydney, Australia. Anatolia, 28(1), 100101. doi:10.1080/13032917.2016.1166418.

Oktadiana, H., Pearce, P.L., Pusiran, A. K., \& Agarwal, M. (2017), Travel career patterns: The motivations of Indonesian and Malaysian muslim tourists. Tourism, Culture and Communication, Vol. 17(4), pp. 231-248. doi:10.3727/109830417X15072926259360.

Pearce, P.L. (2017), Supervising a tourism doctorate: Roles, realities and relationships. Handbook of teaching and learning in tourism (pp. 484498) Retrieved from www.scopus.com.

Pearce, J. R., \& Pearce, P.L. (2017), Retro-methodologies: Insights for city tourism research. International Journal of Tourism Cities, Vol. 3(1), pp. 17-29. doi:10.1108/IJTC-01-2017-0002.

Pearce, P.L., \& Zare, S. (2017), The orchestra model as the basis for teaching tourism experience design. Journal of Hospitality and Tourism Management, Vol. 30, pp. 55-64. doi:10.1016/j.jhtm.2017.01.004.

Wu, M. -., Pearce, P., \& Dong, W. (2017), How satisfying are Shanghai's superior hotels? the views of international tourists. International Journal of Contemporary Hospitality Management, Vol. 29(4), pp. 1096-1115. doi:10.1108/IJCHM-01-2015-0014.

Wu, M. -., \& Pearce, P.L. (2017), A tale of two parks: Tibetan youths' preferences for tourism community futures. Journal of Tourism and Cultural Change, Vol. 15(4), pp. 359-379. doi:10.1080/14766825.2016.1156687. 
Wu, M. -., \& Pearce, P.L. (2017), The rally experience: Exploring motivation patterns of Australian grey nomads. Journal of Destination Marketing and Management, Vol. 6(4), pp. 407-415. doi:10.1016/j. jdmm.2016.06.008.

Wu, M. -., \& Pearce, P.L. (2017), Understanding Chinese overseas recreational vehicle tourists: A netnographic and comparative approach. Journal of Hospitality and Tourism Research, Vol. 41(6), pp. 696-718. doi:10.1177/1096348014550869.

\section{8}

Jin, Q., Pearce, P., \& Hu, H. (2018), The study on the satisfaction of the elderly pe.ople living with their children. Social Indicators Research, Vol. 140(3), pp. 1159-1172. doi:10.1007/s11205-017-1803-1

Li, J., Pearce, P.L., \& Low, D. (2018), Media representation of digital-free tourism: A critical discourse analysis. Tourism Management, Vol. 69, pp. 317-329. doi:10.1016/j.tourman.2018.06.027.

Naidoo, P., \& Pearce, P.L. (2018), Enclave tourism versus agritourism: The economic debate. Current Issues in Tourism, Vol. 21(17), pp. 1946-1965. doi:10.1080/13683500.2016.1235554.

Pabel, A., \& Pearce, P.L. (2018), Selecting humour in tourism settings - A guide for tourism operators. Tourism Management Perspectives, Vol. 25, pp. 64-70. doi:10.1016/j.tmp.2017.11.005.

Pearce, P.L., \& Mohammadi, Z. (2018), Love, romance, and behavior: Finding juliet, finding meaning doi:10.1108/S1571-504320180000024005 Retrieved from www.scopus.com.

Pearce, P.L., \& Wu, M. -. (2018), A mobile narrative community: Communication among senior recreational vehicle travellers. Tourist Studies, Vol. 18(2), pp. 194-212. doi:10.1177/1468797617723469.

Pearce, P.L., \& Wu, M. -. (2018), Entertaining international tourists: An empirical study of an iconic site in china. Journal of Hospitality and Tourism Research, Vol. 42(5), pp. 772-792. doi:10.1177/1096348015598202.

Pharino, C., Pearce, P., \& Pryce, J. (2018), Paranormal tourism: Assessing tourists' onsite experiences. Tourism Management Perspectives, Vol. 28, pp. 20-28. doi:10.1016/j.tmp.2018.06.003.

Wang, W., Wu, J., Wu, M. -., \& Pearce, P.L. (2018), Shaping tourists' green behavior: The hosts' efforts at rural Chinese B\&Bs. Journal of Destination Marketing and Management, Vol. 9, pp. 194-203. doi:10.1016/j. jdmm.2018.01.006

Wang, W., Yi, L., Wu, M. -., Pearce, P.L., \& Huang, S. S. (2018), Examining Chinese adult children's motivations for traveling with their parents. Tourism Management, Vol. 69, pp. 422-433. doi:10.1016/j.tourman.2018.06.024. 
Wang, W. -., Chang, Y., \& Pearce, P.L. (2018), China's first tourism law: Representations of stakeholders' responses. Journal of Tourism and Cultural Change, Vol. 16(3), pp. 309-327. doi:10.1080/14766825.2017. 1298607.

Wu, M. -., \& Pearce, P.L. (2018), Gap time and Chinese tourists: Exploring constraints. Current Issues in Tourism, Vol. 21(10), pp. 1171-1186. doi: 10.1080/13683500.2017.1415868.

Wu, M. -., Pearce, P.L., \& Li, Q. (2018), Chinese behind the wheel: Factors affecting their satisfaction with international self- drive holidays. Journal of Destination Marketing and Management, Vol. 9, pp. 12-19. doi:10.1016/j.jdmm.2017.09.004.

Yagi, C., \& Pearce, P.L. (2018), European castles through Japanese eyes and minds. European Journal of Tourism Research, 19, 5-22. Retrieved from www.scopus.com.

Zare, S., \& Pearce, P. (2018), Order effects and multi-city visits: Tour guides' perspectives. International Journal of Tourism Cities, Vol. 4(2), pp. 194-206. doi:10.1108/IJTC-08-2017-0042.

Zhou, L., Yu, J., Wu, M. -., Wall, G., \& Pearce, P.L. (2018), Seniors' seasonal movements for health enhancement. Service Industries Journal, Vol. 38(1-2), pp. 27-47. doi:10.1080/02642069.2017.1365139.

\section{9}

Huang, K., \& Pearce, P. (2019), Visitors' perceptions of religious tourism destinations. Journal of Destination Marketing and Management, Vol. 14 doi:10.1016/j.jdmm.2019.100371.

Huang, K., Pearce, P.L., Wu, M. -., \& Wang, X. -. (2019), Tourists and buddhist heritage sites: An integrative analysis of visitors' experience and happiness through positive psychology constructs. Tourist Studies, Vol. 19(4), pp. 549-568. doi:10.1177/1468797619850107.

Lee, D., \& Pearce, P. (2019), Shining a light on Asian night markets: Vendors' and visitors' views. International Journal of Tourism Cities, Vol. 6(2), pp. 467-484. doi:10.1108/IJTC-02-2019-0027.

Pabel, A., \& Pearce, P.L. (2019), Developing the humour repertoire concept to guide future tourism-humour research. European Journal of Humour Research, Vol. 7(3), pp. 120-136. doi:10.7592/EJHR2019.7.3.pearce2.

Pabel, A., \& Pearce, P.L. (2019), Humour in supplier-customer interactions: The views of Australian tourism operators. European Journal of $\mathrm{Hu}$ mour Research, Vol. 7(3), pp. 84-100. doi:10.7592/EJHR2019.7.3.pearce.

Pabel, A., \& Pearce, P. L. (2019), Tourism and on-site humour: A perspective article. Tourism Review, Vol. 75(1), pp. 65-68. doi:10.1108/TR-072019-0287. 
Pearce, P.L. (2019), Controlling disturbing tourist behaviour: A perspective article. Tourism Review, Vol. 75(1), pp. 225-227. doi:10.1108/TR06-2019-0260.

Pearce, P.L., \& Wang, Z. (2019), Human ethology and tourists' photographic poses. Annals of Tourism Research, 74, 108-120. doi:10.1016/j. annals.2018.11.002.

Šegota, T., Sigala, M., Gretzel, U., Day, J., Kokkranikal, J., Smith, M., . . . Pearce P.L., (2019), Editorial. International Journal of Tourism Cities, Vol. 5(2), pp. 109-124. doi:10.1108/IJTC-06-2019-111.

Zhang, C. X., Pearce, P., \& Chen, G. (2019), Not losing our collective face: Social identity and Chinese tourists' reflections on uncivilised behaviour. Tourism Management, Vol. 73, pp. 71-82. doi:10.1016/j.tourman.2019.01.020.

\section{0}

Huang, K., Pearce, P., Guo, Q., \& Shen, S. (2020), Visitors' spiritual values and relevant influencing factors in religious tourism destinations. International Journal of Tourism Research, Vol. 22(3), pp. 314-324. doi:10.1002/jtr.2337.

Li, J., Pearce, P.L., \& Oktadiana, H. (2020), Can digital-free tourism build character strengths? Annals of Tourism Research, Vol. 85 doi:10.1016/j. annals.2020.103037.

Oktadiana, H., \& Pearce, P.L. (2020), Losing touch: Uncomfortable encounters with tourism technology. Journal of Hospitality and Tourism Management, Vol. 42, pp. 266-276. doi:10.1016/j.jhtm.2020.01.011.

Oktadiana, H., Pearce, P.L., \& Li, J. (2020), Let's travel: Voices from the millennial female muslim travellers. International Journal of Tourism Research, Vol. 22(5), pp. 551-563. doi:10.1002/jtr.2355.

Oktadiana, H., Pearce, P.L., \& Mohammadi, Z. (2020), Special dietary requirements: Restaurant sector responses across six tourist cities. International Journal of Tourism Research, Vol. 22(4), pp. 507-517. doi: $10.1002 / j$ tr.2352.

Pearce, P.L. (2020), Tourists' perception of time: Directions for design. Annals of Tourism Research, Vol. 83. doi:10.1016/j.annals.2020.102932.

Pharino, C., \& Pearce, P. (2020), Paranormal tourism planning: Stakeholder views on development in south east asia. Tourism Planning and Development, Vol. 17(3), pp. 313-334. doi:10.1080/21568316.2019.1667860.

Rahmafitria, F., Pearce, P.L., Oktadiana, H., \& Putro, H. P. H. (2020), Tourism planning and planning theory: Historical roots and contemporary alignment. Tourism Management Perspectives, Vol. 35. doi:10.1016/j. tmp.2020.100703. 
Tong, Y., Wu, M. -., Pearce, P.L., Zhai, J., \& Shen, H. (2020), Children and structured holiday camping: Processes and perceived outcomes. Tourism Management Perspectives, Vol. 35. doi:10.1016/j.tmp.2020.100706.

Zhang, C. X., \& Pearce, P. (2020), Feeling superior? national identity and humour in British castles. Tourism Recreation Research, Vol. 45(1), pp. 30-41. doi:10.1080/02508281.2019.1632572.

\section{1}

Radomskaya, V., \& Pearce, P.L. (2021), Adding character: The role of destination mascots in tourism development. Tourism Management, Vol. 84. doi:10.1016/j.tourman.2020.104248.

Xu, D., Chen, T., Pearce, J., Mohammadi, Z., \& Pearce, P. L. (2021), Reaching audiences through travel vlogs: The perspective of involvement. Tourism Management, Vol. 86. doi:10.1016/j.tourman.2021.104326.

Xu, D., Pearce, P.L., \& Chen, T. (2021), Deconstructing tourist scams: A social-practice-theory perspective. Tourism Management, Vol. 82. doi:10.1016/j.tourman.2020.104186. 